\title{
Annotation of the book
}

The overarching aim of the book is to demonstrate the dynamics of welfare policies (family support and pension protection) in different socioeconomic settings. It challenges the conventional welfare state research by choosing to compare the most developed welfare states of the Nordic countries with the little-researched welfare states of the three 'young' market-oriented democracies of the Baltic area. By doing so, the book revives 'old' welfare state theories, welfare state models and family policy/gender regimes, and contributes to a better understanding of the complex inequalities that families and individuals are facing in the 21 st century.

The comparative analyses of the Baltic and Nordic welfare state systems respond to a number of theoretical and empirical questions that are relevant to contemporary welfare state studies: what is - or should be - the role of private actors (non-profit organisations and commercial firms) in the welfare state? How should the pay-as-you-go principle be combined with the cumulative principle in reforming pension insurance? What kind of family policy measures can best ensure gender equality and a work-life balance and solve the problems of child poverty?

By addressing policy developments in the field of family support and pension protection in these two groups of welfare states, the book contributes to finding, and reflecting upon, innovative solutions to common or similar challenges in European welfare states.

This book is of great interest to social policy scholars, students and policy makers with an interest in the Baltic and Nordic countries, and in family policy and pension protection reforms, and to those with a general interest in the contemporary welfare state studies in Europe. 
Jolanta Aidukaite, Sven E.0. Hort, and Stein Kuhnle - 9781839106118

Downloaded from PubFactory at 04/25/2023 11:52: 07PM 